\title{
Indonesiskan - ett konstgjort språk som lyckats
}

\section{Av Hans Hägerdal, universitetslektor i historia}

\author{
Länk till presentation av Hans Hägerdal
}

Skillnaderna mellan att studera språk och historia är inte nödvändigtvis särskilt stora. Det finns flera aspekter på detta. Så har ju postmodernisterna lärt oss att språket för historikerna är lika med världen. De har också försökt intala oss att den fiktiva romanen och den historiska berättelsen är av samma skrot och korn. Så fort vi försöker forma en historisk text kommer vi oundvikligen att dras med de begränsningar språket lägger på våra möjligheter att uttrycka oss vetenskapligt. Men språk kan också vara historia på ett mer direkt sätt. Genom att söka efter ordens ursprung, och studera hur de trängt in i språket får vi oss till livs en mängt högintressant information kring politisk historia, kulturhistoria, religionshistoria, och så vidare. Att läsa en text utifrån ett etymologiserande, ordhärledande, perspektiv är att vandra genom historiens innehållsrika salar, att uppleva invasioner och folkvandringar, religiösa omvändelser och kulturella matriser, regimers uppgång och fall. Inte minst intressant blir ett sådant studium då vi rör oss med språk vilkas utbredningsområde och karaktär förändrats starkt under modern historia - kanske till och med uppkommit ganska nyligen. Jag ska här ta upp ett sådant språk. Jag tänker nämligen ge en historisk exposé över indonesiskan, eller Bahasa Indonesia som det egentligen heter.

Indonesien som begrepp har inte funnits speciellt länge. Namnet självt uppfanns av ett par engelska orientalister i mitten av 1800-talet. Man satte helt enkelt samman det geografiska namnet Indien med det grekiska ordet för ö, nesos (jämför Peleponnesos i Grekland). Men namnet användes föga under lång tid. Istället talade man lite löst om Ostindiska Öarna fram till andra världskriget. Som namn på ett land dyker Indonesien upp först 1945. Allt detta betyder ju att ett språk som kallas indonesiska rimligtvis måste vara någonting ganska nytt.

Detta blir än mer uppenbart när man försjunker i en atlas över Indonesien. Vi rör oss med en tropisk önation som innefattar en väldig mängd öar. En del säger 14000 medan andra talar om 17000 - i vilket fall som helst ett försvarligt antal öar. De olika öarna eller ögrupperna har var och en sin historia, sina kulturella egenheter. Ofta har de också sina egna språk. Man finner i dagens Indonesien mer än tvåhundra austronesiska språk och mer än hundrafemtio melanesiska. På en liten ö som Alor i östra delen av önationen, som är stor som en svensk kommun, kan språkvetaren botanisera bland åtta språk och sjuttio dialekter, de flesta obegripliga för grannarna. Det finns språk som talas av tiotals miljoner människor, och det finns språk som bara talas av ett par isolerade byar och knappt ser ut att överleva nästa generation. En del av de här språken har sina egna skriftsystem. Antingen har man använt sig av arabisk skrift och anpassat den till det egna språket (Jawi-skriften). Eller också har man skrivtecken som från början härstammar från Indien. En del av de här systemen använder folk fortfarande, framför allt på Java och Bali (aksara Jawa, aksara Bali). På andra håll är det numera nästan bara lärda personer som känner till de gamla skrivtecknen.

Indonesien präglas alltså av en stor mångfald. Men varifrån kommer då det indonesiska nationalspråket? Varifrån tog man det tungomål som gör att en bybo från Sabang i nordväst kan tala med en bybo från Merauke i sydöst utan större problem? Var hämtade man det som blivit ett kitt för att hålla samman det väldiga och mångskiftande landet? Ja, för att besvara den frågan måste vi gå en bit tillbaka i historien. Indonesien har aldrig i äldre tid utgjort en stat, ett rike, vilket skiljer det från länder som Vietnam, Burma och Thailand. Det var helt enkelt Ostindiska Öarna eller, för att använda en inhemsk 
beteckning, Nusantara, 'arkipelagen'. Istället har det varit europeiska kolonisatörer som tagit initiativet till att samla öarna under en politisk auktoritet. Alltifrån början av 1500talet genomkorsades arkipelagen av portugisiska, spanska, engelska och holländska kölar, på jakt efter kryddor och rikedomar. Alltifrån 1600-talet kom holländarna att dominera på öarna, och under 1800-talet och början av 1900-talet lade de under sig hela det vidsträckta området med våld, hot och diplomati. Ett område som sträckte sig lika långt som från Kap Trafalgar till Ural hade kommit att domineras av den vite mannen.

Som goda kolonisatörer gav holländarna de infödda skor såväl som struktur. Med hjälp av byråkrati och utbildning strukturerade de sin stora ostindiska mjölkkossa (Nederlandsch Oost-Indië) och knöt det ekonomiskt till sitt lilla kalla och platta land borta i Europa. Sin huvudstad och sina viktigaste omsorger förlade man till ön Java, ungefär lika stort som den Apenniniska halvön, en tättbefolkad risodlande miljö där de flesta var och är muslimer. Det var också i första hand på Java som folk började fråga sig en för holländarna synnerligen obehaglig fråga: Kunde man inte strängt taget klara sig bättre utan kolonialherrarna? Under 1900-talets första decennier började allt fler arga unga män svara "jo" på den frågan. Man borde bilda ett alternativ, en rörelse för att arbeta för att frigöra det stora och oenhetliga välde som holländarna snickrat ihop.

År 1928 samlades engagerade aktivister till en ungdomskongress i storstaden Batavia, det vi idag kallar Jakarta. Här hördes det klatschiga slagordet "Ett folk, ett språk, ett hemland: Indonesien". Man dammade alltså av 1800-talsbegreppet Indonesien och tänkte sig att de hundratals folken i Ostindien skulle kunna konstituera sig som ett folk, som en superstam: indonesier. Men för att skapa ett folk måste man ha en viktig gemensam nämnare. Man måste ha ett språk. Var skulle man få det ifrån?

Ett alternativ var det javanesiska språket som ändå pratades av ungefär halva befolkningen i det som skulle bli Indonesien. Men här fanns ett litet aber. Förutom att det inte var alldeles enkelt att lära var javanesiskan var ett socialt väldigt ojämlikt språk. Det kanske kan låta märkligt att ett språk kan vara odemokratiskt, men det var javanesiskan. Det hade olika nivåer beroende på om man talade till en person förnämare eller ringare än en själv. Vissa ord måste man helt enkelt byta ut beroende på vem man tilltalade. Det lät inte riktigt bra för de nymornade nationalisterna som drömde om ett modernt, pluralistiskt, helst demokratiskt samhälle när man väl fått undan holländarna.

Men det fanns ett annat alternativ. På en del håll på Sumatra och Borneo pratade man malajiska, liksom i de engelska kolonierna på Malackahalvön. Det var inget speciellt svårt språk och det var praktiskt att använda som kommunikationsmedel, till exempel handelsmän emellan. Holländarna själva fann det praktiskt att använda malajiska i sina affärer med de infödda. Alltså, kunde man inte ta upp malajiskan som ett nationalspråk och utveckla det, stoppa in alla de moderna termer som måste finnas i det progressiva samhälle man drömde om? Det slog an. Trots att malajiskan bara talades av en mindre del av folk i arkipelagen kunde man nu undvika att javaneserna, den viktigaste folkgruppen, framstod som någon slags förstarangsmänniskor inför de yttre folkslagen. Alla i arkipelagen kunde samlas kring ett språk, indonesiskan.

Indonesien vann sin frihet i en blodig revolution 1945-49 och därefter utvecklades det nya språket snabbt. Det var ett lätt språk att lära, med skonsam grammatik och strikt regelbundna verbformer. Än lättare blev saken av att man valt att skriva det med latinska alfabetet. I Indonesien finns en känd maträtt som kallas gado-gado, en sorts salladsblandning med jordnötssås. Dagens indonesiska är just en gado-gado, där man blandar och ger ingredienser som det faller sig. Här finns ord som egentligen är sanskrit som kom till arkipelagen med besökare från Indien för nästan tusen år sedan, och som ofta stoppats in via javanesiskan. Så har vi wanita (kvinna) och raja (konung). Här finns persiska ord som anlände med influenser från Mellanöstern för många hundra år sedan, till exempel nama 'namn'; man hör att det rör sig om ett indoeuropeiskt språk. Här finns ett och annat som rovgiriga portugisiska sjöfarare bidrog med på 1500-talet och senare: sentosa 'säker' och pesta 'fest'. Här finns arabiska ord som allvarstyngda muslimska 
missionärer predikade: tafsir 'tolkning' och musyawarah 'överläggning'. Här finns holländska ord som låter nästan som ren och skär svenska: handuk 'handduk' och gratis 'gratis', för att inte tala om det oundvikliga lilla ordet ya 'ja'. Och här finns ett väldigt och ständigt ökande antal internationella termer som inte tarvar översättning: internasional, mobil, stabilisasi, telegrap, teknik, demokrasi, universitas och mycket annat. En specialitet är alla akronymerna i indonesiskan. Långa och krångliga uttryck förkortas fyndigt och klatschigt. Västra Borneo, Kalimantan Barat, blir Kalbar. De väpnade specialstyrkorna, Komando Pasukan Khusus, blir Kopassus. Och den förfärliga Asienkrisen, Krisis moneter, kallas familjärt Krismon.

Hur har då detta språk slagit an i den väldiga övärlden? Faktiskt mycket bra. Idag pratar den stora majoriteten av indonesierna ledig indonesiska. Och inte bara det. Konsten att läsa och skriva har ökat drastiskt. När de unga nationalisterna gjorde upp sina nationsbyggarplaner 1928 kunde kanske bara 10-20 procent av männen på öarna läsa och skriva, och bland kvinnorna rörde det sig bara om någon enstaka procent. Idag har det nationella utbildningssystemet väsentligen höjt procentsatsen för de bägge könen till 80 procent eller mer.

Indonesien har under de senaste åren varit ett land som dragits med stora problem, både ekonomiskt och politiskt. Asienkrisen har drabbat Indonesien hårdare än något annat land i regionen, vilket i förlängningen har lett till politiska omvälvningar. Förändringen mot ett mer demokratiskt styrelsesätt efter 1998 har inte hindrat stora slitningar mellan olika grupper av människor. Extremism och etniskt hat har utbrutit med jämna mellanrum i spåren av den störtdykande ekonomin. Om det spridda och mångkulturella landet alls kan överleva som nation i framtiden kommer detta säkert i mycket att vara språkets förtjänst. Ett språk som både är lätt att ta till sig och som är i ständig utveckling efter tidens behov.

\section{(C) Hans Hägerdal}

